\title{
脂肪酸生合成阻害抗生物質セルレニンと
}

\author{
脂 質 代 謝 \\ 大 村 智*.粟 谷 寿 一** \\ $*$ 北里大学薬学部微生物薬品製造学教室 \\ ** 北里研究所抗生物質部門 \\ （東京都港区白金 5-9-1）
}

\section{Lipid Metabolisms and Antibiotic Cerulenin, Inhibitor of Fatty Acid Synthesis}

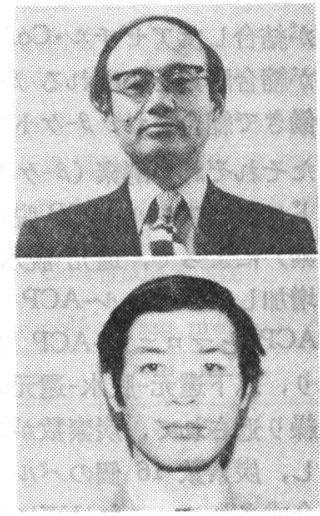

Satoshi ŌMUra and Juichi Awaya

Kitasato University and The Kitasato Institute

(Shirokane, Minato-ku, Tokyo)

\section{1 はじめに}

抗生物質は医薬品, 農薬あるいは飼料添加剤として広 く利用され, 各種病原微生物に上る感染症, ウイルス 病, がんなどの克服, 農産物の増産に多大な貢献をして いる。一方, 抗生物質に関する研究は天然有機化学をは じめ, 細菌学, 生化学などの関連する分野の研究と密接 に結びつき，発展してきた。 ${ }^{13} \mathrm{C}-\mathrm{NMR}$ 利用による生合 成研究, 耐性機構の解明, 作用機構の解明など多くの例 を挙げることができる。その中で, 作用機序の研究は単 にメカニズムを明らかにするにとどまらず，さらにその 作用を利用して, 生命現象の発現にかかわる生体内諸反 応の解明へと進展した。細胞壁合成阻害剤としてのペニ シリン，タンパク合成阻害剛としてのピュロマイシン, RNA 合成阻害剂としてのアクチノマイシンなどがその 好例である。

著者らは抗生物質研究の一環として進めてきた作用機 序解明の研究の中で, 真菌類の生育を強く阻止する抗生 物質セルレニン (cerulenin)（図-1）が脂肪酸生合成の特 異的な阻害作用を有することを明らかにした ${ }^{1), 22}$ 。これ<smiles></smiles>

図-1 セルレニンの化学構造

まで，このような性質を有する抗生物質は見いだされて いなかったことから，本物質は抗菌作用のみではなく， 脂肪酸生合成の阻害剂としても注目されるようになっ
た。その結果, 脂質代謝の関与する生化学研究あるいは 脂肪酸生合成系と類似した縮合反応によって生成する “ポリケタイド”を経て生合成される物質の生合成研究 に利用されるようになった。その一部についてはすでに 著者らの総説1,2)があるので，それを参照していただく として, 本稿ではセルレニンの作用機序の概略とセルレ ニンを利用した最近の脂質代謝と抗生物質の生合成に関 する研究について述べたい。

\section{2 セルレニンの作用機序}

生体にとってパルミチン酸, オレイン酸などの長鎖脂 肪酸はリン脂質, 中性脂質などの前駆物質として, 細胞 膜の構造々機能の発現に重要な役割を演じている3”。長 鎖脂肪酸は図-2 に示した経路によって生合成される“。

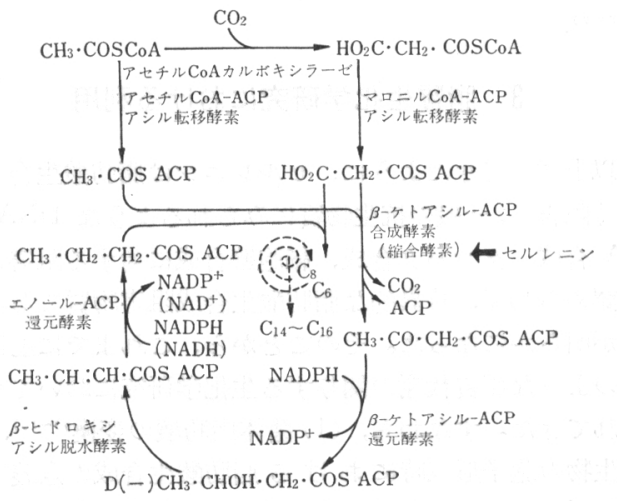

図-2 飽和脂肪酸の生合成 (大腸菌) とセルレニンの作用点

すなわち，アセチル・CoA が出発物質となり,この物質 
がアセチル・CoAカルボキシラーゼによって炭酸化され て，マロニル・CoA が生成する。アセチル・CoA とマ ロニル・CoA にアシル・キャリヤー・プロテイン (ACP) が結合したアセチル・CoA-ACP とマロニル・CoA-ACP が縮合酵素とよばれる $\beta$-ケトアシル-ACP 合成酵素の 働きで縮合され， $\beta$-ケトブチル-ACP となり，図に示し たそれぞれの酵素 ( $\beta$-ケトアシル-ACP 還元酵素, $\beta$-ヒ ドロキシアシル-ACP 脱水酵素, エノール-ACP 還元酵 素）によって，還元一脱水一還元がおこり，炭素数が 2 個 増加したブチリル-ACP が生成される。このブチリルー $\mathrm{ACP}$ とマロニル-ACP との間に再び縮合反応がおこ り, 以下還元一脱水-還元のサイクルが 繰り返されて，炭素数が 2 個ずつ増加 し，炭素数 16 個のパルミチン酸が生 合成される。これは更に別の酵素系に よって長鎖化が行われ，炭素数 18 個 のステアリン酸をはじめとする，より 炭素数の多い脂肪酸が生合成されると ともに，不飽和化も行われ菌体脂肪酸 を構成する。細菌, 植物などでは図-2 に示した酵素が活性を有する状態で分 離可能であるが，酵母や動物などでは これらの反応がすべて複合酵素系で行 われる。生物の種類によってこれら 2 種類のタイプの酵素系が存在すること が知られている5)。セルレニンは縮合 酵素である $\beta$-ケトアシル-ACP 合成 酵素の反応を阻害することにより，脂 肪酸生合成を阻害し，その結果として 微生物の生育を阻止する。

また，七ルレニンはステロール生合成系における $\beta$ ヒドロキシル・メルルグルタリル・CoA $(\mathrm{HMG} \cdot \mathrm{CoA})$ が 生合成される段階, すなわち $\mathrm{HMG} \cdot \mathrm{CoA}$ 合成酵素を 阻害するが，脂肪酸合成系に対する阻害系に比べて弱 $\left({ }^{6), 7)}\right.$ 。

\section{3 脂質生化学研究における利用}

以上述べてきたように，セルレニンは脂肪酸生合成を 強く阻害し，一般の抗生物質にみられるような DNA, R NA 合成, タンパク合成, 細胞壁合成に対する阻害作用 は認められず，特異的な脂肪酸生合成阻害物質であるこ とが明らかになった。そのことから，これまでに主に以 下のような脂質代謝の関与する生化学研究において利用 されてきた。すなわち，(1) 菌体脂肪酸の変換 ${ }^{8) ~ 10),(2) ~}$ 微生物の胞子形成時における脂肪酸生合成の意義 ${ }^{11)}$, （3）ポリケタイドを経て生合成される代謝産物（マクロ

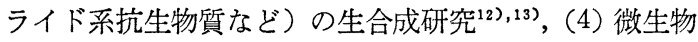

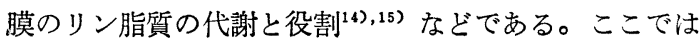

最近の研究成果について述べる。

\section{1 胞子発芽時における脂質生合成の意義}

著者らはセルレニンによって酵母（Saccharomyces cerevisiae）の胞子形成が阻止され，長鎖脂肪酸（パル ミチン酸とオレイン酸）の添加で形成が回復されるこ之 から, 胞子形成時における脂肪酸生合成の重要性を推測 したが ${ }^{11)}$ ，最近，系状菌の胞子発芽に㧍ける脂肪酸生合 成の意義がセルレニンを用いることによった明らかにさ れつつある。

Brambl’らは Botryodiplodia theobramae の胞子発芽 におけるセルレニンの影響老調べ，図-3 に示したよう
•コントロール；セルレニン ○: $5 \mu \mathrm{g} / \mathrm{ml}, \Delta 10 \mu \mathrm{g} / \mathrm{ml}$,

図-3 B. theobramae の胞子発芽速度に 対するセルレニンの影響

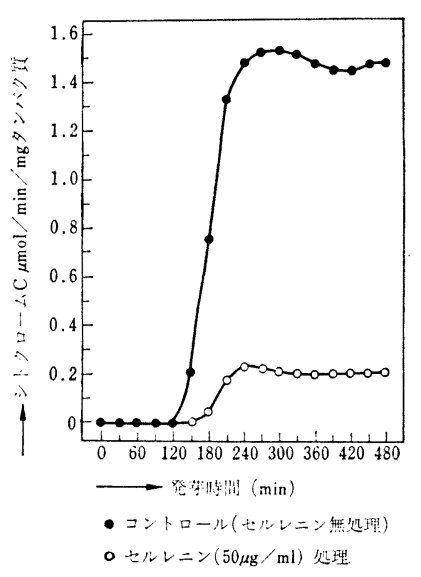

図-4 B. theobramae の胞子発芽時 におけるシトクロムcオキシダ 一ゼ活性に対するセルレニンの 影響

に $50 \mu \mathrm{g} / \mathrm{ml}$ の濃度で $95 \%, 100 \mu \mathrm{g} / \mathrm{ml}$ でほぼ完全に発 芽の阻止が捛こることを明らかにしている(16)17。これ は胞子をセルレニン処理することによって, ミトコンド リア中のシトクロム $\mathrm{c}$ オキシダーゼ活性が無処理の対照 に比べて 1/7 以上に抑制されたためであるとし(図-4)， さらに $8 \mathrm{~h}$ ，セルレニン処理した胞子シトクロムパター ンはシトクロムa (604 nm) が正常の胞子に比べて 3 倍 に増加したことを明らかにした (図-5 $)^{17)}$ ここれらの事 実はセルレニンの胞子発芽阻害が脂肪酸生合成阻害を介 してミトコンドリアの呼吸系を妨害することに起因する ものと推測している。また, この時, セルレニン処理し た胞子のタンパク， RNA 合成も阻害されるが，この現 象はセルレニンによる脂肪酸生合成阻害の二次的な影響 によるものであろうとのべている。

一方, Nickerson と Leastman \& Rhizopus stolonifer の胞子のう(震)胞子の発芽について調べ，胞子の発芽は セルレニン濃度 $4 \mu \mathrm{g} / \mathrm{ml}$ で完全に阻止されることを明ら かにしている。しかしながら, 彼らの実験結果によれば, 発芽の少なくとも $2 \mathrm{~h}$ 以内ではタンパク合成, RNA 合 


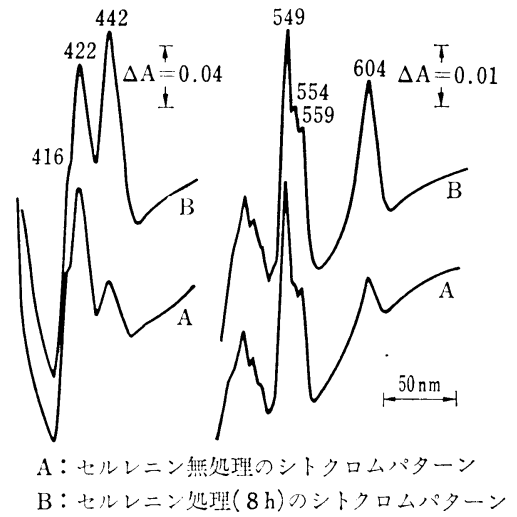

図-5 B. theobramae 胞子のミトコンドリアシトクロ ムに対するセルレニンの影響

成， $\mathrm{O}_{2}$ の uptake にもセルレニンの影響はみられない と報告している ${ }^{18)}$ 。七ルレニンの脂肪酸生合成阻害によ って引き起こされろ二次的な影響については Brambl ら の結果と Nickerson らのそれには相反するものがあり， その真疑の究明は今後に待たねばならないが，いずれに しても, 微生物の胞子形成時のみではなく, 発芽時にお いても, 脂質代謝が重要な役割を演じていることがセル レニンを用いることによって証明されたわけである。

\section{2 脂肪酸活性化酵素欠損変異株の分離之脂質代謝}

先に述べた脂肪酸生合成（図一2）における律速段階は アセチル・CoA カルボキシラーゼの関与するアセチル・ CoA のカルボキシル化にあるといわれており，この酵 素の調節機構については沼らの一連の研究19),20),21) で明 らかになりつつある。それによれば，動物あるいは微生 物細胞に㧍ける長鎖脂肪酸の生成はアセチル・CoA カル ボキシラーゼの活性を低下させる，いわゆるアロステリ ックな作用を示す。事実, 培地中に長鎖脂肪酸を添加し て酵母 (Saccharomyces cerevisiae) を培養すると, ア セチル・CoA カルボキシラーゼの活性は低下する。長鎖 脂肪酸によるこのような酵素の抑制作用は酵素活性の抑 制ではなく，酵素生成の抑制であるといわれている。

沼らはさらに脂肪酸生合成の調節機構を解明するに は，長鎖脂肪酸による抑制作用が脂肪酸そのものでおこ るのか，あるいは脂肪酸の何らかの代謝産物によるもの かを追求する必要があるとした。そのためには脂肪酸活 性化酵素であるアシル・CoA 合成酵素を特異的に阻害す る物質を利用するか，あるいはこの酵素の欠損した変異 株を分離して調べるかの 2 通りの方法がある。ところが， 今のところアシル・CoA 合成酵素の特異的な阻害剤は見 いだされておらず，変異株を分離する必要があった。そ こで, 彼らは脂肪酸生合成阻害䬉であるセルレニンを使 ってアシル・CoA 合成酵素欠損変異株を分離した ${ }^{22), 23) 。 ~}$ S. cerevisiae では de novo の脂肪酸生合成が行われて いる条件下ではアシル・CoA 合成酵素は㗢かないため,
あらかじめセルレニンで de novo の脂肪酸生合成を阻 害し，培地中に長鎖脂肪酸（パルミチン酸）を添加し， アシル・CoA 合成酵素によって活性化された長鎖脂肪酸 そよって酵母を生育させることを利用した。従って，七 ルレニンとパルミチン酸の存在下ではアシル・CoA 合成 酵素の欠損した微生物の集落は出現しないはずである。

この原理によって, 分離された変異株, B-53, B-201 のアシル・CoA 合成酵素活性は 表-1 に示したとおりで

表-1 親株と変異株のアシル・CoA合成酵素活性

\begin{tabular}{l|r|c}
\hline \multirow{2}{*}{ 菌 } & \multicolumn{3}{|c}{ 比活性 $(\mathrm{nmol} / \mathrm{min} / \mathrm{mg}$ protein) } \\
\cline { 2 - 3 } X $2180-1 \mathrm{~B}$ & 実 験 1 & 実 験 2 \\
B-201 & 50.8 & 45.8 \\
B-53 & 1.2 & 1.0 \\
\hline
\end{tabular}

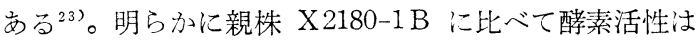
著しく低下している。この変異株齐脂肪酸添加と無添加 の条件下で，培養した時のアセチル・CoA カルボキシラ 一ゼ活性は 表-2 に示した ${ }^{23)}$ 。親株では脂肪酸を添加し

表-2 親株と変異株のアセチル・CoA カルボキシ ラーゼ活性

\begin{tabular}{c|l|c|c}
\hline \multirow{2}{*}{ 実験 } & \multirow{2}{*}{ 菌 } & \multicolumn{2}{|c}{ 比活性 $(\mathrm{nmol} / \mathrm{min} / \mathrm{mg}$ protein) } \\
\cline { 2 - 4 } 1 & 脂肪酸無添加 & 添 加* \\
\hline \multirow{2}{*}{1} & $\mathrm{X} \mathrm{2180-1} \mathrm{B}$ & 11.3 & $6.0(53)^{* *}$ \\
& $\mathrm{~B}-201$ & 6.6 & $5.8(88)$ \\
& $\mathrm{B}-53$ & 11.0 & $9.6(87)$ \\
& $\mathrm{X} 2180-1 \mathrm{~B}$ & 11.5 & $5.9(51)$ \\
& B-201*** & 8.6 & $7.7(90)$ \\
& B-53 & 11.2 & $10.0(89)$ \\
\hline
\end{tabular}

* 添加した脂肪酸 (パルミチン酸, オレイン酸, リノレン 酸，おのおの $1 \mathrm{mM}$ )

**（）無添加の比活性て詨与る比率（\%)

*** $33^{\circ} \mathrm{C}$ で培養

て培養した菌体の酵素活性は無添加のそれに比べて約50 \%の值を示したのに対して，変異株では 87〜90\%の酵 素活性を示した。このことはS. cerevisiae における長 鎖脂肪酸のアセチル・CoA カルボキシラーゼに対する抑 制作用は脂肪酸そのものによってではなく, アシル・ CoA 合成酵素によってアシル化を受け，何らかの代謝 産物として作用発現がおこっていること亦すものであ る。

一方，炭化水素資化性酵母であ万Candida lipolytica は $n$-アルカンや長鎖脂肪酸を唯一の炭素源として生育 する。この時のアセチル・CoA カルボキシラーゼ活性は グルコースで生育させた条件下の時よりも著しく低く, これは酵素の生成が抑制されていると解釈される ${ }^{24)}$ 。従 って, 脂肪酸の調節機構の分子レベルでの解明にはこの ような酵母を利用することがより望ましいと考えられ 
る。そこで, 先の S. cerevisiae の変異株分離の場合と 同様の原理で C. lipolytica のアシル・CoA 合成酵素欠 損変異株 L-5，L-7 が分離され，その性質が調べられ $た^{25)}$ 。S. cerevisiae の変異株の場合と同様, L-5, L-7 株のアシル・CoA 合成酵素活性はグルコース生育菌にお いても，オレイン酸生育菌においても低い(表-3)。と ころが，これらの変異株は不思議なことに，長鎖脂肪酸 や $n$-アルカンを唯一の炭素源として培養した時におい ても，親株と同様に生育した。また長鎖脂肪酸，n-アル カンで生育した菌体脂肪酸の組成を調べてみると, 親株 に比べて奇数脂肪酸の割合が著しく低下していた（表 -4)。このことはこの変異株が基質とした脂肪酸や $n$-ア

表-3 グルコースあるいはオレイン酸で生育した菌体 のアシル・CoA 合成䤃素活性

\begin{tabular}{l|c|c}
\hline \multirow{2}{*}{ 菌 株 } & \multicolumn{2}{|c}{ 比活性 (nmol/min/mg protein) } \\
\cline { 2 - 3 } グルコース生育菌体|オンイン酸生育菌体 \\
\hline Y-6795 (親株) & 60.7 & 41.6 \\
L-5 & 0.7 & 2.8 \\
L-7 & 0.7 & 2.7 \\
RL 7-1 & 74.6 & 50.4 \\
RL 7-2 & 63.8 & 46.3 \\
RL 7-8 & 60.0 & 45.2 \\
\hline
\end{tabular}

RL 株は L-7 株のリバータント。

表-4 脂肪酸あるいは $n$-フルカンで生育した菌体の 奇数脂肪酸の割合

\begin{tabular}{|c|c|c|c|c|}
\hline & \multicolumn{4}{|c|}{ 奇数脂肪酸の割合 $(\%)$} \\
\hline & $\begin{array}{l}\text { ペソタデ } \\
\text { カン酸 }\end{array}$ & $\begin{array}{l}\text { テトラデ } \\
\text { カン酸 }\end{array}$ & $\begin{array}{l}n \text {-ヘプタデ } \\
\text { カン }\end{array}$ & $\begin{array}{l}n \text { n-オクタデ } \\
\text { カン }\end{array}$ \\
\hline $\mathrm{Y}-6795$ & 94.7 & 2.3 & 98.5 & 3.0 \\
\hline $\mathrm{L}-5$ & 6.1 & 0.6 & 14.3 & 2.6 \\
\hline $\mathrm{L}-7$ & 5.8 & 0.4 & 28.3 & 2.6 \\
\hline RL 7-1 & 91.7 & 2.5 & - & - \\
\hline RL 7-8 & 93.2 & 1.4 & 一 & - \\
\hline
\end{tabular}

ルカンの酸化で得られる脂肪酸をそのまま活性化して取 り込む酵素（従来のアシル・CoA 合成酵素）は確かに欠 いているけれども， $\beta$-酸化するために活性化する酵素 （新しいアシル・CoA 合成酵素）は保持していることを 示すものである。従って，これらの現象から長鎖脂肪酸 を活性化する酵素は 2 種類存在するのではないかと推定 されたわけである。

変異株の保有している新しいアシル・CoA 合成酵素 （以下合成酵素 II しし，従来の酵素を合成酵素Ｉとする） は通常の反応系では測定できず，反応液にホスファチジ ルコリンを加えることによって測定可能となった ${ }^{26)}$ 。変 異株 L-7 のグルコース，オレイン酸それぞれの炭素源 で生育した菌体中のアシル・CoA 合成酵素 I，II を測定 してみると，表-5 のようになり，ホスファチジルコリ ンを加えない従来の測定法で検出される合成酵素 I の活
表-5 変異株 L-7 株のアシル・ CoA 吕成酵素 I の欠損

\begin{tabular}{|c|c|c|c|c|c|}
\hline \multirow{3}{*}{ 炭素源 } & \multirow{3}{*}{ 分 } & \multicolumn{3}{|c|}{ 活 性 $(\mathrm{nmol} / \mathrm{min})$} & \multirow{3}{*}{$\mathrm{b} / \mathrm{a}$} \\
\hline & & \multicolumn{2}{|c|}{ ホスファチジルコリン } & \multirow[b]{2}{*}{$\mathrm{b}-\mathrm{a}$} & \\
\hline & & (a) 無添加 & (b) 添加 & & \\
\hline \multirow[t]{3}{*}{ オレイン酸 } & ホモジネート & 60 & 1390 & 1330 & 23.2 \\
\hline & 上澄み液 & 22 & 48 & 26 & 2.2 \\
\hline & 沈 殿 物 & 37 & 1037 & 1000 & 28.0 \\
\hline \multirow[t]{3}{*}{ グルコース } & ホモジネート & 8 & 222 & 214 & 27.8 \\
\hline & 上澄み液 & 3 & 9 & 6 & 3.0 \\
\hline & 沈 殿 物 & 2 & 153 & 151 & 76.5 \\
\hline
\end{tabular}

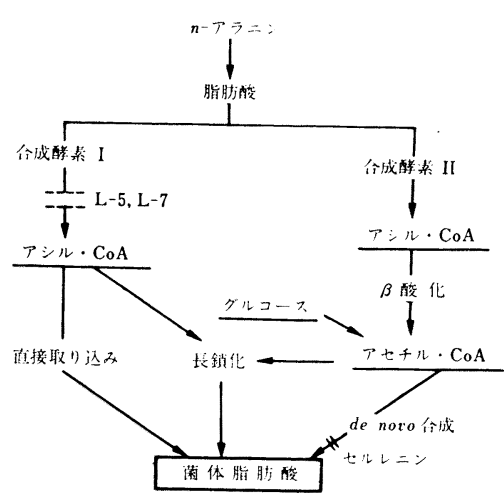

図-6 C. lipolytica 9脂肪酸生合成経路 ${ }^{27)}$

性はグルコース，オレイン酸培地ともに微少であり，本 変異株が合成酵素 IIのみを保有していることが明らかに されたわけである。

C. lipolytica でのアシル・ CoA 合成酵素 I, II と脂 肪酸生合成系との関倸を図示すると図-6 のようになり， それぞれの醭素の役割が理解できる。前述の上うに変異 株が奇数脂肪酸をほとんど蓄積しないことは $n$-アルカ ン生育酵母菌体であっても, 通常の炭素源で生育した菌 体とほぼ同じ菌体脂肪酸組成を有するものであり，タン パク資源としての利用といら観点から興味深いものであ り，今後の研究の成果が期待されている28)。

\section{4 抗生物質生合成研究への利用}

抗生物質をはじめとする天然有機化合物の中には，先 に述べた脂肪酸生合成系と類似したアセタート，マロナ 一トあるいはこれらに似かよった低級脂肪酸が縮合し て, その基本骨格を形成する生合成機構をもったものが 多くみられる。最も簡単な例として1個のアセタートと 3 個のマロナートの縮合から生合成される 6-メチルサ リチル酸 (6-MSA) の場合を図-7 に示す ${ }^{12)} 。$

スピラマイシンの場合は 図-8 に示すように, アセタ 一ト，マロナート，2-メチルマロナート，2-エチルマロ ナートなどが縮合して, この抗生物質の特徴であるラク トンを形成する。セルレニンはこれらの物質の生合成を 


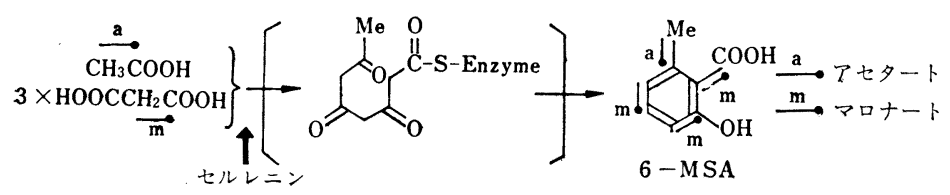

図-7 6-MSA の生合成

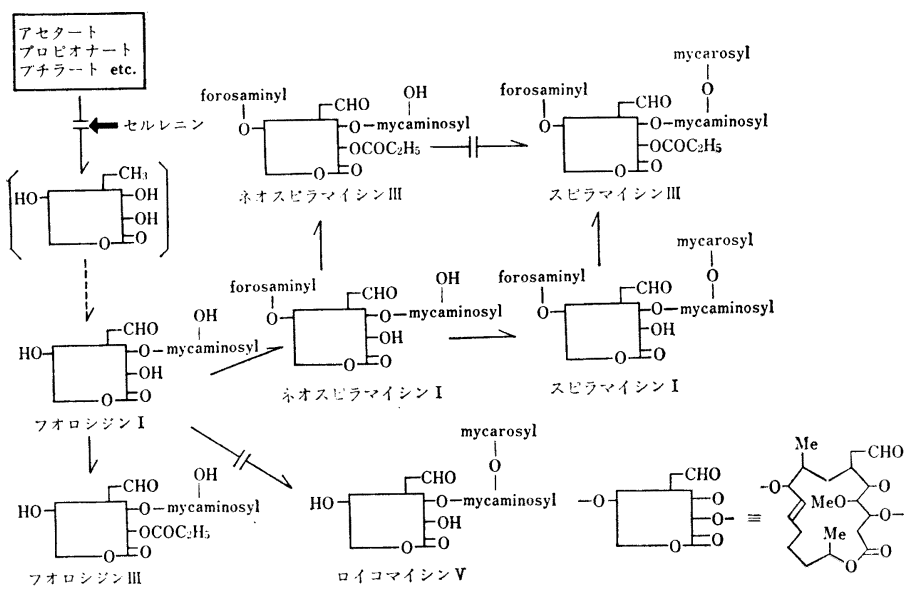

図-8 スビラマイシンの生合成の最終段階

も阻害する ${ }^{12), 13)}$ 。その阻害部位は脂肪酸の生合成の場 合と同じ縮合の段階であることはペプチド抗生物質とか アミノグリコシド抗生物質などアミノ酸や糖から生合成 される抗生物質の生合成はセルレニンによって作用を受 けないことから容易に推定される。スピラマイシンの生 合成の後半である糖が結合していく過程とラクトン 3 位 の水酸基がアシル化を受けるステップとの関連を知るた めに, 生産培地にセルレニンを加え, ラクトン部の生合 成を阻害した条件下で, 必要な各化合物を培地に加え て，生産菌によってどのように変換されるかを調べた。 ラクトン部, 3 位のヒドロキシル基のアシル化は $3 つ$ の糖の結合が完了した最後の段階で行われることが判明 した ${ }^{29)}$ 。のようにしてセルレニンは脂肪酸の生合成と その他の天然物の生合成によって行われるアセタート, マロナート（あるいはメチルマロナート）などの縮合反 応が近似することを示すのみならず，これを用いてこれ より後半の生合成経路の解明に優れた試薬となってい る。

\section{5 おわりに}

これまでの脂質代謝研究におけるセルレニンの利用は 次のように大別することができる。(1) 脂肪酸生合成の 阻害を in vitro, in vivo の系で直接に観察するもの, （2）生命現象における脂質代謝の関与を証明するもの, （3）人為的に脂質代謝をコントロールして, 生命現象を 解明するもの。数年前までに利用された例としては大部 分が (1)，(2) に類するものであり，本稿で述べた胞子
発芽に関する研究もそれにあたるである う。しかしながら, 3.2 項でとりあげた 変異株の分離に応用するといら利用法は （3）に相当するものであり，抗生物質の 特異的作用を有効に活用した 好例であ る。セルレニンの作用機作が脂肪酸の生 合成阻害にあることが明らかにされてか ら,すでに 5 年以上を経過した今日, 極 めて多くの人々により, これが用いられ て研究が行われているが, 今後の研究の 発展を興味哚くみつ放ていきたい。ま た, 抗生物質の利用が医薬品としての利 用だけではなく, 広く生化学の研究に活 用され，その進歩に寄与することをも期 待したい。 (昭和 53 年 11 月 27 日受理)

\section{文献}

1）大村 智, 栗谷寿一, 化学々生物, 12, 787 (1974)

2) S. Ōmura, Bacterial. Rev., 40, 681 (1976)

3）日本生化学会編, “生化学実験講座 14 , 生体膜”, 東京化学同人 (1977) p. 141

4）舟橋三郎, 原一郎, 山川民夫, “脂質 2 ”, 共立出版 (1972) p. 1

5) D.N. Brindley, S. Matsumura, K. Block, Nature, 224, 666 (1969)

6) T. Ohno, J. Awaya, T. Kesado, S. Ōmura, Bio= chem. Biophys. Res. Comm., 57, 1119 (1974)

7) M.D. Greenspan, R.C. Mackow, S. Ōmura, Lipids, 12, 729 (1977)

8) J. Awaya, T. Ohno, H. Ohno, S. Ōmura, Biochem. Biophys. Acta, 409, 267 (1975)

9) S. Rottem, M.F. Barile, Antimicrob. Agents. Chemo= ther., 9, 301 (1976)

10) A. Tanaka, T. Hagihara, Y. Nishikawa, M. Mishi= na, S. Fukui, Eur. J. Appl. Microbiol., 3, 115(1976)

11) T. Ohno, J. Awaya, S. Ōmura, Antimicrob. Agents Chemother., 9, 42 (1976)

12) H. Ohno, T. Ohno, J. Awaya, S. Ōmura, J. Bio= chem. (Tokyo), 78, 1149 (1975)

13) H. Takeshima, C. Kitao, S. Ōmura, J. Biochem. (Tokyo), 81, 1127 (1977)

14) J.E. Cronan, Jr., Proc. Natl. Acad. Sci. U.S.A., 71, 3758 (1974)

15) J.E. Cronan, Jr., E.P. Gelmann, Bacteriol. Rev., 39, 232 (1975)

16) R. Brambl, Arch. Biochem. Biophys., 182, 273 (1977)

17) R. Brambl, H. Wenzler, M. Josephson, J. Bacteri= ol., 135, 311 (1978)

18) K.W. Nickerson, E. Leastman, Exp. Mycol., 2, 26 (1978)

19) T. Kamiryo, S. Numa, FEBS Lett., 38, 29 (1973)

20) S. Numa, S. Yamashita, Curr. Top. Cell. Regul., 8, 197 (1974)

21) K. Kitajima, S. Tashiro, S. Numa, Eur. J. Bio= chem., 54, 373 (1975) 
22) T. Kamiryo, S. Parthasarathy, M. Mishina, Y. Iida, S.Numa, Agric. Biol. Chem., 41, 1295 (1977)

23) T. Kamiryo, S. Parthasarathy, S. Numa, Proc. Nat. Acad. Sci. U.S.A., 73, 386 (1976)

24) M. Mishina, T. Kamiryo, A. Tanaka, S. Fukui, S. Numa, Eur. J. Biochem., 71, 301 (1976)

25) T. Kamiryo, M. Mishina, S. Tashiro, S. Numa, Proc. Natl. Acad. Sci. U.S.A., 74, 4947 (1977)
26) M. Mishina, T. Kamiryo, S. Tashiro, S. Numa, Eur. J. Biochem., 82, 347 (1978)

27) A. Tanaka, T. Hagihara, T. Kamiryo, M. Mishina, S. Tashiro, S. Numa, S. Fukui, Eur. J. Appl. Microbiol. Biotechnol., 5, 78 (1978)

28）福井三郎, 川本進, 田中渥夫, 醱酵工学, 56, 436 (1978)

29) S. Ōmura, C. Kitao, H. Ikeda, Chem. Pham. Bull., 27, 176 (1979) 